\title{
DESKRIPSI MARKETING MIX JASA PENDIDIKAN SEKOLAH DASAR MUHAMMADIYAH KUTOARJO
}

\author{
Nurhidayati*, Supriyono, Muhammad Ferdian \\ Universitas Muhammadiyah Purworejo \\ e-mail: nurhidayati@umpwr.ac.id*
}

\begin{abstract}
ABSTRAK
Penelitian ini bertujuan untuk mendeskripsikan marketing mix jasa pendidikan SD Muhammadiyah Kutoarjo yang terdiri dari produk, harga, lokasi, promosi, SDM, bukti fisik dan proses pembelajaran. Metode penelitian yang di gunakan adalah metode kualitatif. Teknik pengumpulan data dengan cara wawancara, observasi dan dokumentasi. Analisis data dalam penelitian ini menggunakan analisis non statistik, dengan model analisis mengalir (flow model of analysis). Marketing mix jasa pendidikan adalah kegiatan promosi mengenai produk, harga , lokasi, barang bukti/ prasarana sekolah dan proses kegiatan sekolah yang di lakukan sumber daya manusia sekolah.

Kata kunci: jasa pendidikan, marketing mix , Muhammadiyah
\end{abstract}

\section{PENDAHULUAN}

Dokumen ini adalah template untuk versi Word (doc). Bila anda dapat menggunakan versi dokumen ini sebagai referensi untuk menulis manuscript anda. Pendahuluan menguraikan latar belakang permasalahan yang diselesaikan, isu-isu yang terkait dengan masalah yg diselesaikan, ulasan penelitan yang pernah dilakukan sebelumnya oleh peneliti lain yg relevan dengan penelitian yang dilakukan.

Dinamika pola pendidikan yang begitu cepat dan silih berganti menjadikan persaingan antar sekolah semakin ketat, khususnya dalam menarik konsumen dan meningkatkan loyalitas pelanggan dalam bentuk pelayanan jasa. Sekolah merupakan lembaga pendidikan non profit yang bergerak dalam bidang jasa pendidikan yang melayani konsumen berupa murid, peserta didik, mahapeserta didik, dan juga masyarakat umum (stakeholder) (Wijaya, 2012; Alma, 2005). Pelayanan kepada konsumen jasa pendidikan ditujukan untuk menambah kepercayaan masyarakat sekaligus promosi sekolah. Sekolah, terutama sekolah swasta, dalam mendapatkan konsmen/peserta didik memerlukan strategi pemasaran. Menurut (Gronroos, 1994; 
Bennett, 2013) bauran pemasaran adalah alat pemasaran terkendali yang memadukan perusahaan untuk menghasilkan respon yang diinginkan oleh pasar sasaran. Unsurunsur bauran pemasaran tersebut adalah 4P, product, price, place, dan promotion. Marshall \& Johnson (2010) dalam Handayani (2017) menyebutkan bahwa konsep/ elemen pemasaran tradisional 4P kurang memadai sehingga perlu penambahan 3P tersebut. Hal itu karena jasa memiliki karakteristik yang berbeda dengan produk, yaitu tidak berwujud (intangibility), tidak terpisahkan (inseparability), dan tidak tahan lama (perishability). Dengan demikian dapat disimpulkan bahwa bauran pemasaran adalah alat pemasaran yang terdiri dari 7 elemen, yaitu product, price, place, promotion, people, physicalevidence, dan process.

Saat ini banyak bermunculan sekolah swasta unggulan yang menawarkan beragam fasilitas, bahkan dengan biaya bersaing menambah maraknya kompetisi pendidikan. Dalam hal ini penyelenggara pendidikan dituntut lebih kreatif dlama menggali keunikan dan keunggulan sekolahnya agar dibutuhkan dan diminati oleh pelanggan jasa pendidikan. Oleh karena itulah strategi pemasaran jasa pendidikan diperlukan untuk meningkatkan ketertarikan masyarakat terhadap sekolah.

Begitu juga dengan SD Muhammadiyah Kutoarjo. Sejak berdirinya SD Muhammadiyah Kutoarjo tahun 1970, masyarakat kutoarjo dan sekitarnya menaruh kepercayaan terhadap lembaga pendidikan ini. Pelayanan sekolah yang diberikan kepada peserta didik semakin bagus. Begitu juga dengan prestasi akademik dan prestasi non akademik yang semakin melejit. Setiap tahunnya puluhan piala hasil kejuaraan diperoleh dari berbagai lomba, baik dari tingkat kecamatan, kota, maupun nasional. Keunggulan tersebut menjadi daya Tarik tersendiri bagi sekolah. Peningkatan jumlah peserta didik yang bertambah secara signifikan dari tahun ke tahun.

Menurut Lockhart dalam Wijaya (2012: 16), marketing jasa pendidikan merupakan cara untuk melakukan sesuatu dimana peserta didik, orang tua, sekolah, dan masyarakat menganggap sekolah sebagai institusi pendukung masyarakat yang bertujuan melayani pelanggan jasa pendidikan. Alma (2005: 45) menyebutkan bahwa pemasaran jasa pendidikan berarti kegiatan lembaga pendidikan memberi layanan atau menyampaikan jasa pendidikan yang memuaskan kepada konsumen. Sedangkan Kotler 
(2009: 5) mendefinisikan pemasaran yang digunakan pada lembaga pendidikan yaitu analisis, perencanaan, pelaksanaan, dan pengendalian program yang dirumuskan secara hati-hati, dirancang untuk menghasilkan pertukaran nilai secara sukarela dengan pasar sasaran jasa pendidikan untuk mencapai tujuan sekolah.

Suatu lembaga pendidikan akan mendapat kepercayaan dari masyarakat apabila lembaga tersebut bermutu, dengan banyaknya prestasi yang diraih dalam kurun waktu tertentu.Selain itu, masyarakat/orang tua dapat memperoleh apa yang diinginkan dari pendidikan untuk anaknya, sehingga orang tua akan merasa kebutuhan akan pendidikan anaknya terpenuhi.

Wijaya (2012: 21) menyatakan bahwa kebutuhan pemasaran jasa pendidikan muncul ketika sekolah menetapkan transaksi yang diharapkan oleh pasar sasaran jasa pendidikan. Gray (1992) dalam Wijaya (2012: 17) menyatakan bahwa sekolah membutuhkan strategi pemasaran jasa yang membutuhkan orientasi pemasaran khusus.

\section{METODE PENELITIAN}

Penelitian ini menggunakan metode kualitatif atau naturalistik, yaitu penelitian yang menggunakan lingkungan alamiah sebagai sumber data (Sutama, 2016: 64). Studi dilakukan pada waktu interaksi berlangsung di tempat kejadian. Penelitian kualitatif ini menggunakan manusia sebagai instrumen penelitian .Desain penelitian ini menggunakan pendekatan fenomenologis. Pendekatan ini menurut Sumardjoko (2015: 8) digunakan untuk memahami makna berbagai peristiwa dan interaksi manusia dalam situasi khusus. Peristiwa yang dimaksud adalah segala aktivitas yang berhubungan dengan kegiatan marketing jasa pendidikan di SD Muhammadiyah Kutoarjo.

Penelitian ini menggunakan analisis non statistik, dengan model analisis mengalir (flow model ofanalysis), artinya penelitihanya mendeskripsikan data-data yang terkumpul kemudian dianalisis untuk mendapatkan makna dan ditarik kesimpulan (Sumardjoko, 2015: 29-31). 


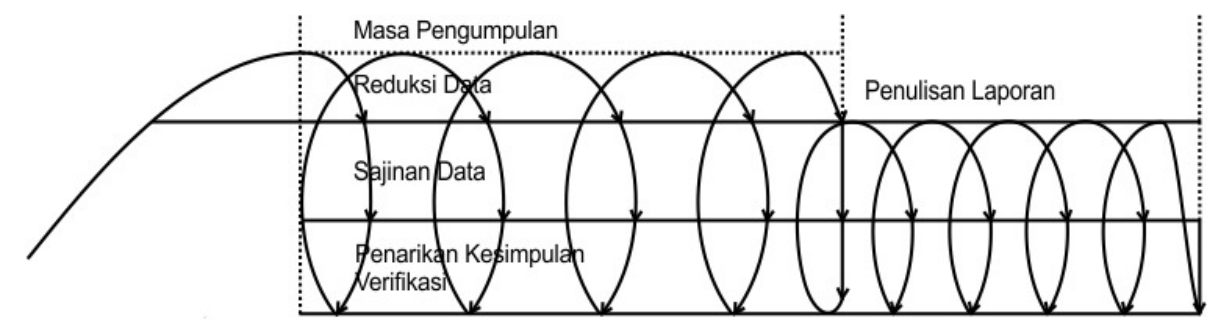

Gambar 1: Model Analisis Mengalir

Gambar 1 menunjukkan bahwa proses analisis dilakukan bersamaan dengan proses pengumpulan data. Ketiga komponen analisis dilakukan bersama pada waktu kegiatan pengumpulan data. Saat peneliti menyusun fieldnote lengkap, reduksi data segera dibuat dan diteruskan dengan penyusunan sajian data, kemudian dibuat kesimpulan sementara, karena proses pengumpulan data masih berlangsung. Begitu mendapatkan data baru segera diadakan perubahan, sehingga kesimpulan sementara tersebut akan berubah secara tepat. Demikian seterusnya hingga seluruh data selesai terkumpul.

\section{HASIL PENELITIAN DAN PEMBAHASAN}

Hasil penelitian tentang bauran marketing jasa pendidikan di SD Muhammadiyah Kutoarjo terkait dengan produk, harga, tempat, promusi, orang, bukti fisik, dan proses. Masing-masing diuraikan singkat berikut.

\section{Produk (Product)}

a. SD Muhammadiyah Kutoarjo sangat berpotensi untuk dalam peningkatan prestasi akademik, non akademik maupun keagamaan. Potensi ini cukup besar mengingat daya dukungnya yang besar pula.

b. Produk unggulan berupa program unggulan, kegiatan ekstrakurikuler dan prestasi peserta didik dipromosikan melalui berbagai media yang dapat menjangkau masyarakat kutoarjo

c. dan sekitarnya, bahkan lebih luas lagi.

d. Sekolah melibatkan peserta didik dalam pemasaran jasa pendidikan dengan cara mempublikasikan mereka melalui berbagai media.

e. Pelayanan prima dari para guru dan karyawan untuk para peserta didik menjadi salah satu alat untuk memasarkan jasa pendidikan di SD Muhammadiyah Kutoarjo.

\section{Harga (Price)}

a. Harga/biaya pendidikan tidak dipublikasikan secara luas, hanya di brosur PPDB yang dicetak terbatas untuk calon peserta didik yang akan mendaftar.

b. Biaya pendidikan dihitung secara global satu tahun, sehingga tidak ada lagi pungutan biaya tambahan selama tahun ajaran berjalan. 


\section{Tempat (Place)}

a. Lokasi sekolah yang berada di tengah kota kutoarjo namun suasana yang sanagt asri menjadikan lingkungan yang sangat nyaman untuk melaksanakan proses pembelajaran hal ini menjadi unggulan pemasaran SD Muhammadiyah Kutoarjo.

b. Akses menuju SD Muhammadiyah Kutoarjo sangat mudah dijangkau. Meskipun mudah diakses, sekolah juga menyediakan fasilitas antar jemput bagi peserta didik yang membutuhkan.

c. Gedung sekolah berada di lokasi sekolah cukup luas, yaitu seluas $4.409 \mathrm{~m}^{2}$, membuat peserta didik lebih leluasa bergerak.

\section{Promosi (Promotion)}

a. SD Muhammadiyah Kutoarjo melakukan promosi langsung namun lebih banyak melaku- kan promosi tidak langsung, melalui media sosial, media elektronik. Promosi dilaku- kan oleh semua elemen sekolah, mulai dari peserta didik, guru, hingga kepala sekolah, den- gan mempublikasikan keunggulan prestasi sekolah, peserta didik, guru, dan kepala sekolah.

b. Bentuk-bentuk promosi berupa liputan kegiatan-kegiatan sekolah, prestasi kejuaraan baik akademik maupun non akademik hingga tampilan peserta didik di berbagai kegiatan kota maupun provinsi. Selain itu sekolah juga membangun kemitraan dengan instansi pemerintah maupun swasta.

c. Sekolah melakukan terobosan promosi jasa pendidikan melalui program kemitraan dengan lingkungan hingga Humas Pemerintah Daerah Kota Kutoarjo, sehingga publikasi jasa pendidikan dan prestasi SD Muhammadiyah Kutoarjo bisa lebih luas.

d. Keberhasilan promosi sekolah menunjukan peningkatan peminat peserta didik yang signifikan setiap tahunnya.

\section{Orang (People)}

a. Jumlah SDM yang besar sangat berpotensi untuk peningkaan mutu sekolah. Peningkatan kompentensi dan kesiapan Sumber Daya Manusia menjadi syarat mutlak pelayanan SD Muhammadiyah Kutoarjo. Upaya peningkatan mutu SDM dilakukan dengan berbagai kegiatan.

b. Keberhasilan/prestasi yang dicapai oleh peserta didik, guru, dan kepala sekolah menjadi daya panggil dan rasa percaya masyarakat terhadap layanan jasa pendidikan SD Mu- hammadiyah Plus Kota Salatiga.

\section{Bukti Fisik (Physical Evidence)}

a. Gedung SD Muhammadiyah Kutoarjo sangat representatif sebagai sarana pendidikan, dengan lingkungan yang sangat mendukung. Sarana prasarana yang ada sudah memenuhi standard nasional.

b. Sepanjang tembok pagar menuju ke gedung sekolah menjadi tempat strategis untuk menampilkan prestasi yang diraih sekolah, baik peserta didik, guru, 
maupun kepala sekolah.

c. Sarana pelengkap dan penujang pembelajaran seperti kantin, toko alat tulis dan foto kopi, halaman parkir, serta masjid berada di lokasi sekolah.

d. potensi dan bakat peserta didik, dengan berbagai kegiatan pembelajaran baik di dalam kelas/ sekolah, outing class, dan field trip. Kegiatan outing class disesuaikan dengan tema tiap level kelas dan kegiatan field trip ke luar kota dengan tujuan dan sasaran yang berbeda-beda.

e. Penyampaian program pembelajaran dilakukan langsung ketika pertemuan wali murid setiap awal semester. Informasi lainnya mengenai pembelajaran disampaikan juga melalui grup media sosial (WA) wali murid untuk setiap kelas yang dikoordinir oleh wali kelas.

\section{PEMBAHASAN}

\section{Produk (Product)}

SD Muhammadiyah Kutoarjo sangat berpotensi untuk dalam peningkatan prestasi akademik, non akademik maupun keagamaan. Potensi ini cukup besar mengingat daya dukungnya yang besar pula. Dalam mengelola produk jasa pendidikan diperlukan pendekatan yang menyeimbangkan kekayaan budaya dan kekayaan dalam Islam. Prediksi perilaku masyarakat terhadap nilai-nilai keislaman yang mendukung bauran pemasaran (El- Bassiouny, 2016).

Daya dukung dari peserta didik dan orang tua peserta didik sangat besar terhadap sekolah, selain dari pihak sekolah sendiri. Sekolah berupaya maksimal untuk meningatkan mutu, salah satunya ditunjukkan dengan peningkatan kemampuan rata-rata peserta didik dalam berprestasi baik akademik maupun non akademik. Peningkatan kualitas layanan institusi pendidikan sangat berpengaruh terhadap kepuasan pelanggan sehingga dampaknya akan meningkatkan kepercayaan masyarakat terhadap lembaga pendidikan tersebut (Hermawan, 2016).

Produk jasa pendidikan yang paling menonjol secara fisik adalah peserta didik. Sekolah yang bagus menurut penilaian masyarakat memiliki karakteristik peserta didik yang mampu memenuhi dan melebihi standar pendidikan (Wijaya, 2012;93). Sekolah tersebut antara lain memiliki tingkat keberhasilan pembelajaran yang tinggi, prestasi belajarnya menonjol, dan hasil ujian tinggi. Keberhasilan sekolah dalam meningkatkan prestasi belajar akan berpengaruh signifikan terhadap keputusan masyarakat untuk memilih sekolah (Handayani, 2017).

Produk unggulan berupa kegiatan ekstrakurikuler dan prestasi peserta didik dipromosikan melalui berbagai media yang dapat menjangkau masyarakat Kutoarjo dan sekitarnya, bahkan lebih luas lagi. Hal ini merupakan salah satu penerapan bauran pemasaran dengan cara menawarkan produk-produk unggulan (Anwar, 2014). Publikasi aktivitas ekstrakurikuler yang diselenggarakan di SD Muhammadiyah 
Kutoarjo berhasil menarik perhatian peserta didik dan orang tua peserta didik. Orang tua merasa mendapat saluran informasi bakat dan minat karena program ekstrakurikuler dapat meningkatkan pengalaman belajar peserta didik. Hal ini akan menjadi kesempatan bagi sekolah untuk lebih berkembang dan meningkatkan prestasi. Pengelolaan kegiatan ekstrakurikuler yang baik akan menjadi peluang keberhasilan peserta didik di sekolah. Oleh karena itu sekolah harus menyediakan sumber daya yang memadai dan mendukung program ekstrakurikuler, menjalin kerjasama dengan pihak luar yang terkait seperti tenaga ahli di luar sekolah, hingga sumber daya pendidikan tambahan atau pelatih. Kegiatan ekstrakurikuler dan kegiatan sekolah yang variatif akan menjadi faktor yang mendukung marketing jasa pendidikan (Triaji, 2017).

Pelayanan prima dari para guru dan karyawan untuk para pesera didik menjadi salah satu alat untuk memasarkan jasa pendidikan di SD Muhammadiyah Kutoarjo. Keramahan, sikap terbuka, mau membantu dan melayani peserta didik maupun orang tua peserta didik akan menjadi kesan tersendiri bagi pengguna jasa pendidikan. Hal ini akan menjadi merk (brand) yang dapat memberi kontribusi besar dalam menciptakan lingkungan fisik sekolah lebih baik dan menciptakan citra publik yang lebih baik pula (Garoufallou, 2013). Bentuk pelayanan prima termasuk kualitas perilaku guru dan karyawan. Kualitas tersebut memberi dampak terhadap persepsi peserta didik tentang pendidikan berkualitas tinggi. Guru harus memiliki keterampilan berkomunikasi dan pengajaran yang memadai. Guru menguasai metode pengajaran yang paling sesuai dengan berbagai alat pengajaran, berpengetahuan luas, antusias, dan ramah (Sultan,2010).

Di sisi lain, staf akademik (tenaga kependidikan) juga mampu melayani peserta didik maupun orang tua dengan informasi yang tepat dan bekerja efisien. Pelayanan pendidikan prima kepada peserta didik dan wali peserta didik, serta kerjasama yang baik antar komponen pendidikan menjadi salah satu strategi pemasaran yang interaktif (Ngaripin, 2011). Setiap sekolah yang ingin bertahan harus memperhatikan layanan pemasaran untuk menarik lebih banyak peserta didik, yaitu dengan menerapkan prinsip-prinsip pemasaran. Oleh karena itu dibutuhkan model pemasaran baru yang dapat diandalkan, sehingga menarik calon peserta didik baru (Alipour, 2012).

\section{Harga (Price)}

Biaya pendidikan di SD Muhammadiyah kutoarjo berbeda untuk setiap jenjang kelas. Lebih tinggi jenjang kelasnya lebih mahal biaya yang dibayarkan. Penentuan harga dalam bauran pemasaran jasa pendidikan sangat penting. Aktivitas penentuan ini berkaitan dengan pendapatan yang akan diterima sekolah. Semakin banyak kegiatan dan tantangan untuk meningkatkan prestasi sekolah tentu saja 
membutuhkan pembiayaan yang lebih besar. Keputusan penentuan harga sangat penting karena akan menentukan seberapa jauh jasa pendidikan dinilai pelanggan jasa pendidikan dan membantu proses pembentukan citra sekolah. Dengan kata lain, penentuan ini akan memberi dampak persepsi tertentu dan nilai lebih dalam memberi pelayanan yang baik dari sekolah (Anwar, 2014).

Biaya pendidikan tidak dipublikasikan secara luas, hanya pada brosur PPDB yang dicetak terbatas, untuk calon peserta didik yang akan mendaftar. Secara global biaya pendidikan di SD Muhammadiyah kutoarjo cukup tinggi. Biaya pendidikan dihitung secara global untuk 1 tahun ajaran, sehingga orang tua peserta didik tidak lagi dipungut biaya termasuk kegiatan dan ulangan umum. Harga tinggi yang harus dibayarkan tentu dipengaruhi oleh kualitas produk jasa pendidikan yang ditawarkan oleh sekolah. Apabila kualitas produk jasa pendidikan tersebut tinggi, maka pemakai jasa (peserta didik/orang tua peserta didik) tidak segan untuk membayar harga jasa yang lebih tinggi selama masih terjangkau. Penerapan bauran pemasaran dengan cara menawarkan produk-produk unggulan ini juga dilakukan di Muallimin Yogyakarta, dengan menerapkan harga bersaing dengan lembaga lain (Anwar, 2014).

Biaya pendidikan di SD Muhammadiyah kutoarjo dihitung secara global untuk 1 tahun ajaran. Sehingga orang tua peserta didik tidak lagi dipungut biaya tambahan.Perhitungan biaya pembayaran secara global akan banyak memberi manfaat bagi orang tua peserta didik. Perhitungan biaya pendidikan secara global ini memberi dampak positif bagi pengguna jasa pendidikan di SD Muhammadiyah kutoarjo. Orang tua menjadi lebih yakin karena tidak ada lagi kesan bahwa sekolah selalu menarik dana pendidikan.

SD Muhammadiyah kutoarjo sebagai lembaga pendidikan memberi pelayanan sesuai ciri khas sekolah. Sebaliknya, pelanggan sebagai pengguna jasa berhak mendapatkan pelayanan sesuai yang mereka inginkan, yang memuaskan selera mereka. Layanan yang mereka dapatkan berupa layanan dalam bentuk fisik bangunan, sampai berbagai fasilitas dan guru yang berkualitas. Mereka akan ikut melihat, mengawasi, dan memberikan masukan apabila ada hal-hal dirasa kurang memuaskan. Dengan kata lain konsep kualitas layanan berbasis pelanggan sangat berarti bagi pembuat kebijakan yang akan mengembangkan ukuran kualitas pendidikan (Munhurrun, 2013).

\section{Lokasi (Place)}

Lokasi sekolah yang berada tengah kota menjadi unggulan pemasaran SD Muhammadiyah kutoarjo. Lingkungan sekolah sangat mendukung proses belajar mengajar. Penentuan lokasi jasa pendidikan akan mempengaruhi pilihan calon pelanggan jasa pendidikan dalam menentukan pilihannya. Lokasi pendidikan yang ideal adalah yang jauh dari kebisingan. Bangunan sekolah yang merupakan sumber 
daya fisik menjadi salah satu daya tarik pengguna jasa pendidikan. Faktor pendukung lainnya adalah lokasi dan bentuk bangunan. Fisik sekolah akan mempengaruhi keputusan pelanggan jasa pendidikan untuk memilih sekolah. Dari sisi penyelengga jasa, bangunan sekolah ditempatkan seiring dengan pesan bahwa sekolah menyampaikan jasa pendidikan kepada peserta didik yang potensial (Triaji, 2017).

Pertimbangan lain pemilihan lokasi oleh penyelenggara jasa selain faktor fisik di atas adalah akses virtual, yaitu keterjangkauan fasilitas internet. Tersedianya situs web sekolah dan pemasaran jasa pendidikan yang berbasis teknologi informasi, akan menjadi daya tarik masyarakat untuk memilih sekolah (Triaji,2017). Informasi sekolah dapat diperoleh pengguna jasa pendidikan tanpa harus datang ke lokasi/sekolah.

Akses menuju SD Muhammadiyah kutoarjo mudah dijangkau meskipun berada jauh di tengah kota. Meskipun mudah diakses, sekolah juga menyediakan fasilitas antar jemput bagi peserta didik yang membutuhkan. Pilihan calon pelanggan jasa berdasarkan lingkungan sekolah, ketersediaan lahan parkir, kondisi lingkungan belajar, transportasi dan akses menuju sekolah. Orang tua juga akan mempertimbangkan jarak, waktu, dan efisiensi ketika memilih suatu sekolah. Akses untuk mencapai lokasi sekolah dikatakan mudah apabila mudah dijangkau oleh transportasi umum (Alma,2005) dalam Wijaya (2012;142). Kompetitifnya layanan pendidikan menyajikan kemampuan untuk mempertahankan keunggulan kompetitif dan bersaing di pasar layanan pendidikan. Salah satu indikatornya adalah sarana prasarana dan kepuasan pelanggan (Ivanenko, 2015).

Gedung sekolah baru berada di lokasi sekolah cukup luas, yaitu seluas $4.709 \mathrm{~m}^{2}$, membuat peserta didik lebih leluasa bergerak. Sekolah telah menyediakan ruang bebas bagi anak untuk dapat leluasa bergerak. Hal ini merupakan bentuk fasilitas sekolah untuk kepuasan pelanggan/peserta didik. Kualitas layanan akan berpengaruh terhadap kepuasan peserta didik (Faizan Ali, 2014).

\section{Promosi (Promotion)}

SD Muhammadiyah Kutoarjo melakukan promosi langsung namun lebih banyak melakukan promosi tidak langsung, melalui media sosial, media elektronik. Promosi dilakukan oleh semua elemen sekolah, mulai dari peserta didik, guru, hingga kepala sekolah, dengan mempublikasikan keunggulan prestasi sekolah, peserta didik, guru, dan kepala sekolah. Aktivitas publisitas merupakan penerbitan informasi positif tentang sekolah dan kulaitas jasa pendidikan dengan cara yang berbeda-beda. Dengan kata lain, aktivitas tersebut adalah cara untuk menginformasikan kepada masyarakat secara obyektif dengan melibatkan seluruh elemen sekolah. Tujuan promosi jasa pendidikan antara lain untuk menarik perhatian dan minat pengguna jasa pendidikan, mengimbangi promosi jasa pendidikan yang dilakukan oleh sekolah kompetitor, dan 
mendorong lebih banyak calon peserta didik. Kegiatan pomosi dan publikasi suatu lembaga pendidikan memang efektif diadakan secara langsung. Dengan taktik pemasaran differensiasi (keberadaan positif) dengan menetapkan teori bauran pemasaran (Anwar, 2014).

Bentuk-bentuk promosi berupa liputan kegiatan-kegiatan sekolah, prestasi kejuaraan baik akademik maupun non akademik hingga tampilan peserta didik di berbagai kegiatan kota maupun propinsi. Selain itu sekolah juga membangun kemitraan dengan instansi pemerintah maupun swasta. Sekolah juga melakukan terobosan promosi jasa pendidikan melalui program kemitraan dengan lingkungan hingga Humas Pemerintah Daerah Kota kutoarjo, sehingga publikasi jasa pendidikan dan prestasi SD Muhammadiyah Kutoarjo bisa lebih luas.

Kemitraan antar lembaga bertujuan untuk mempermudah komunikasi dan birokrasi dalam marketing jasa pendidikan. Kegiatan kemitraan ini tentu memberikan keuntungan bagi kedua belah pihak, oleh karena itu kemitraan yang terjalin tidak hanya sebatas promosi tetapi lebih membawa manfaat bagi kedua belah pihak. Inti dari berbagai aktivitas promosi yang dilakukan dengan berbagai bentuk kegiatan, adalah untuk menarik minat pelanggan jasa pendidikan. Pemasaran jasa sosial/pendidikan perlu memikirkan solusi tepat di luar masalah teknis, kognitif, dan sasaran yang berfokus pada organisasi, agar dapat diakses oleh orang- orang yang sebenarnya membutuhkan Russell-Bennet (2013).

\section{Orang (People)}

Keungulan SDM SD Muhammadiyah kutoarjo dengan beragam kempetensi menjadi modal utama bagi pengembangan institusi. Pengelolaan SDM yang besar harus dilakukan dengan baik, terarah, dan terencana, agar dapat mengoptimalkan kinerja dan kompetensi yang dimilikinya. Keleluasaan yang diberikan kepala sekolah kepada para guru untuk mengembangkan diri untuk mengoptimalkan kinerja dan kompetensi yang dimilikinya. Efektifitas sekolah dapat ditingkakan dengan meningkatkan kondisi pekerjaan guru, membangun saluran komunikasi yang efektif dan menawarkan pelatihan pendidikan guna meningkatkan kepuasan dan efektifitas guru (Hung, 2012).

Peningkatan mutu SDM di SD Muhammadiyah kutoarjo ditujukan untuk meningkatkan kompetensi pelayanan terhadap kepuasan peserta didik, yaitu dengan keahlian dan pengetahuan yang dibutuhkan untuk melakukan pekerjaan. Hal ini dapat dilihat dari kualifikasi akademik, gelar, dan sertifikasi yang dimiliki. Pemetaan dan penetapan guru secara terstruktur sudah memenuhi unsur proporsional dengan mempertimbangkan kecakapan/keahlian dan masa kerja. Strategi marketing dieksplorasi untuk meraih perhatian calon pengguna jasa pendidikan sekaligus 
mempromosikan citra jasa dan produk yang dihasilkan, serta mempertahankan pelanggan (Iqbal, 2016).

Keberhasilan/prestasi yang dicapai oleh siswa, guru, dan kepala sekolah menjadi daya panggil dan rasa percaya masyarakat terhadap layanan jasa pendidikan SD Muhammadiyah kutoarjo. Kualitas guru, kepala sekolah dan karyawan mendapat perhatian serius dari yayasan. SD Muhammadiyah kutoarjo memiliki guru-guru yang produktif, dapat menunjukkan loyalitas, prestasi, kelancaran, dan stabilitas sekolah. Orang tua siswa akan memiliki tingkat kepuasan yang tinggi apabila mereka puas, aktif, dan menyetujui seluruh usaha yang telah dilakukan sekolah. Ada kecenderungan orang tua dan siswa memilih produk yang sudah memiliki brand atau sudah dikenal di masyarakat, termasuk diantaranya memilih sekolah. Sekolah membutuhkan pendekatan dan pengembangan pemasaran dan membranding supaya bisa terus bertahan dan berkembang (Gavin Suss, 2013).

\section{Bukti Fisik (Physical Evidence).}

Gedung SD Muhammadiyah kutoarjo sangat representatif sebagai sarana pendidikan, dengan lingkungan yang sangat mendukung. Sarana prasarana yang ada sudah memenuhi standart nasional. Bukti fisik memegang peran penting dalam mendukung pemasaran jasa pendidikan suatu lembaga pendidikan. Peran penting tersebut antara lain dapat memengaruhi persepsi pengguna jasa pendidikan. Bukti fisik merupakan tampilan luar sekolah yang dapat membentuk kesan pertama. Lingkungan fisik sekolah akan menjadi peluang menyampaikan citra sekolah. Tata letak bangunan sekolah menggambarkan citra tertentu, seperti membangkitkan reaksi positif melalui interaksi dari banyak rangsangan yang kompleks (Wijaya, 2012;226). Artinya, rancangan fisik sekolah dapat membantu menyampaikan pesan, perilaku, dan hubungan baik yang dapat dirasakan pengguna jasa pendidikan. Sekolah melakukan diferensiasi jasa pendidikan dan membuat sarana fisik semenarik mungkin, untuk menjaring pelanggan jasa pendidikan. Hal ini tentu saja akan menimbulkan emosi positif dan motivasi, sekaligus membangun harapan bagi para orang tua calon siswa, jika menyekolahkan anaknya ke SD Muhammadiyah Kutoarjo maka akan berprestasi pula. Seperti dalam penelitian Alipour (2012), bahwa pemasaran baru untuk sekolah swasta berdasarkan pada sikap oang tua siswa.

Sarana pelengkap dan penujang pembelajaran seperti kantin, toko alat tulis dan foto kopi, perpustakaan, halaman parkir, serta masjid berada di lokasi sekolah.Lingkungan sekolah dirancang untuk membantu dan memudahkan proses penyampaian jasa pendidikan, juga meningkatkan produktivitas sekolah. Keberadaan sarana pendukung di lingkungan sekolah memudahkan seluruh SDM dalam memberikan pelayanan bagi pengguna jasa pendidikan. Karakteristik menyeluruh dari lingkungan sekolah membuat proses perancangan lingkungan sekolah sebagai seni, 
yaitu cenderung berfokus pada jenis-jenis bukti fisik jasa pendidikan. Gagasan efisiensi operasional lembaga dan strategi pemasaran ini terlihat saling berkaitan (Cherkunova, 2016).

\section{Proses (Process)}

Kegiatan pembelajaran yang menyenangkan dilakukan untuk mengoptimalkan potensi dan bakat siswa, dengan berbagai kegiatan pembelajaran baik di dalam kelas/sekolah, outing class, dan field trip. Kegiatan outing class disesuaikan dengan tema tiap level kelas dan kegiatan field trip ke luar kota dengan tujuan dan sasaran yang berbeda-beda. Proses pada bauran pemasaran menunjukkan di mana jasa pendidikan diperoleh dan bagaimana mengelolanya. Manajemen proses jasa pendidikan yang efektif menjadi faktor pembeda sekolah yang kuat, karena terkait dengan cara sekolah memperlakukan peserta didik. Faktor pendukung bauran pemasaran berupa keunggulan khusus dan kegiatan yang variatif, termasuk student trip menjadi daya tarik sekolah (Triaji, 2017).

Proses jasa pendidikan sangat penting, sebagi penunjang keberhasilan marketing jasa pendidikan dan memberikan pelayanan untuk kepuasan pelanggan jasa pendidikan. Tentu saja sekolah harus memperhatikan mekanisme proses penyaluran jasa pendidikan dari sekolah kepada peserta didik. Kualitas layanan pendidikan berpengaruh terhadap kepuasan peserta didik, yang akhirnya mempengaruhi citra kelembagaan. Kepuasan tersebut menjadikan peserta didik semakin loyal terhadap pendidikan tempat mereka belajar (Faizan Ali, 2014).

Penyampaian program pembelajaran dilakukan langsung ketika pertemuan wali murid setiap awal semester. Informasi lainnya mengenai pembelajaran disampaikan juga melalui grup media sosial (WA) wali murid. Untuk setiap kelas yang dikoordinir oleh wali kelas masing-masing. Proses peningkatan layanan jasa pendidikan oleh SD Muhammadiyah kutoarjo dilakukan secara terus menerus dan berkelanjutan, sejak penerimaan siswa baru hingga kelulusan. Layanan tersebut antara lain dilakukan dalam bentuk kemudahan komunikasi sekolah kepada orang tua siswa. Dengan komunikasi yang mudah, melalui media sosial elektronik, dirasa lebih efisien dan dapat menekan biaya operasional sekolah. Hasilnya, orang tua siswa dapat menerima informasi dengan cepat dan dapat mengikuti perkembangan siswa secara maksimal. Pemasaran berbasis informasi telah memberi daya tarik tersendiri bagi masyarakat dalam menentukan pilihan sekolah (Triaji, 2017).

\section{KESIMPULAN}


Product/Produk sekolah dikembangkan sesuai potensi keungulan prestasi akademik, non akademik, dan keagamaan, melalui promosi di berbagai media dengan melibatkan siswa, dan pelayanan prima dari seluruh elemen sekolah. Price/biaya pendidikan berbeda untuk setiap jenjang kelas, tidak dipublikasikan secara luas, dan biaya pendidikan dihitung secara global untuk 1 tahun ajaran berjalan, sehingga orang tua tidak dibebani lagi biaya-biaya tambahan. Place/lokasi sekolah didukung lingkungan yang nyaman untuk proses belajar mengajar, jauh dari keramaian kota namun mudah diakses. Promotion/Promosi dilakukan secara langsung maupun tidak langsung dengan menggunakan berbagai media, menjalin kemitraan dengan instansi pemerintah maupun swasta sebagai bentuk terobosan-terobosan pemasaran jasa, hingga meraih predikat sekolah unggulan di Jawa Tengah.

People/sumber daya manusia yang berkompeten, berprestasi dan berpotensi meningkatkan mutu sekolah. Physical evidence/bukti fisik sekolah sangat representatif, beberapa tempat cukup strategis untuk digunakan sebagai media promosi, serta fasilitas fisik lainnya sebagai pelengkap dan penunjang pembelajaran. Process/Proses pembelajaran dilakukan dengan metode yang menyenangkan dan variatif serta penggunaan media sosial sebagai sarana informasi dengan orangtua peserta didik.

\section{SARAN}

Saran bagi Peneliti selanjutnya diharapkan dapat menggunakan metode lain dan scope yang lebih luas dalam meneliti marketing mix jasa Pendidikan sehingga dapat menemuka formula yang tepat dalam menentuka strategi promosi yang efektif dan efisien.

\section{DAFTAR PUSTAKA}

Alipour, Mehrdad; Aghamohammadi, Ali; Ahmadi, Reza and Hoseini, and Seyyed Hadi. (2012). A New Educational Marketing Mix: The 6Ps for Private School Marketing in Iran. Research Journal of Applied Scienc, Engineering and Technology 4 (21): 4314- 4319, 2012. ISSN:2040-7467.

Alma, Buchari.(2005). Marketing Stratejik Jasa Pendidikan. Bandung: Alfabeta.

Anwar, Dedik Fatkul.(2014). "Strategi Pemasaran Jasa Pendidikan Dalam Meningkatkan Peminat Layanan Pendidikan di Madrasah Muallimin Muhammadiyah Yogyakarta". Tesis gelar Magister Ilmu Agama Islam. Program Studi Pendidikan Islam UIN Sunan Kalijaga. http://digilib.uinsuka.ac.id/15112/2/1220411215_bab-i_iv-atau-v_daftar-pustaka.pdf

Assauri, Sofjan. 2014. Manajemen Pemasaran, Dasar, Konsep, dan Strategi. Rajawali Press, Jakarta. 
Cherkunova, N.G.(2016) The Formation of Marketing Strategy of the Higher Educational Institutions to Increase their Efficiency. International Journal of Economics and Financial Issues. Vol. 6 (S2) 37-42. ISSN: 2146-4138.

El-Bassiouny, N .(2015). Where is Islamic Marketing Heading? A Commentary on Jafari and Sandikci'c (2015) Islamic Consumers, Market and Marketing. Journal of Business Research. Vol 11/No. 1.

Bennett, Rebekah Russell., Metthew Wood., dan Jo Previte.(2013). Fresh Ideas: Services Thinking for Social Marketing. Journal of Social Science. Vol. 3 No. 3. Pp. 223-238.DOI 10.1108/JSOCM-02-2013-0017

Kotler, Philip and Gary Amstrong. 2012. Prinsip-prinsip Pemasaran. Edisi 13. Jilid 1. Erlangga, Jakarta.

Handayani, Asih. (2017). Analisis Bauran Pemasaran Terhadap Keputusan Mahasiswa Memilih Program Studi (Studi di Fakultas Ekonomi Universitas Bojonegoro). Tesis Gelar Magister Administrasi Pendidikan. UMS. Tidak dipublikasikan.

Hermawan, Dadang. (2016). A Study on STIKOM Bali's Student Satisfaction Level in Service Education. International Refereed Research Journal. Vol. VII/No. 2. DOI URL:http:// dx.doi.org/10.18843/rwjasc/v7i2/11

Hung, Chih Lung.(2012). Internal Marketing, Teacher Job Satisfaction and Effectiveness of Central Taiwan Primary School. Social Behavior and Personality Journal. Vol. 40 (9)/ pg. 1435-1450. DOI:https://doi.org/10.2224/sbp.2012.40.9.1435

Iqbal, Samer. (2016). Insight of School Head About Marketing Education Services Through Digital Media. Journal of Education and Educational Development. Vol. 3 (1). pp 52- 73. DOI:http://dx.doi.org/10.22555/joeed.v3i1.711

Ivanenko, N.A., Khairove, IV., Fajzrakhmanova, A.L., Khalilova, T.V., Kharisova, G.M., Lisizina, T.B., \&, Fanusovna, Svetlana.(2015). Competitiveness of Professional Education: Purposes, Tasks and Factors of Its Participation in the International Educational Services Market. Asian Social Science. Vol. 11 (1).pp 369-374. (Online Published: December 2, 2014 doi:10.5539/ass.v11n1p369

Munhurrun, Prabha R.(2013). Service quality measurement for secondary school setting. Quality Asurance in Education. Vol. 21. No.4. DOI: 10.1108/QAE-052011-0025.

Sugiyono, (2012), Metode Penelitian Pendidikan Pendekatan Kuantitatif, Kualitatif, dan $R \& D$, Bandung: Alfabeta.

Sultan, Parves., Wong Ho. (2010). Performance-Based Service Quality Model: an Empirical Study on Japanese Universities. Quality Assurance in Education. Vol. 18 No. 2. Pp 126 - 143. DOI 10.1108/09684881011035349.

Sumardjoko, Bambang. (2015). Diktat Perkuliahan Metodologi Penelitian Kualitatif. Universitas Muhammadiyah Surakarta. 
Suss, Gavin. ( 2013). The Next Revolution Will Be In Education: A New Marketing Approach for Schools. Keter Group: Journal of International Eduction Research, Inovtivation Center, Vo. 12/No. 1. DOI https://doi.org/10.19030/jier.v9i1.7499

Sutama. (2016). Metode Penelitian Pendidikan Kuantitatif, Kualitatif, PTK, R\&D. Kartasura: Fairuz Media. 